\title{
Maximizing RUSUNA Development in TOD Jakarta- Case Study TOD Lebak Bulus Jakarta
}

\author{
Berry Chaerul Basyir ${ }^{1, *}$, Hendrajaya Isnaeni $^{1}$ \\ ${ }^{1}$ Universitas Indonesia, Department of Architecture, 16424 Depok, Indonesia
}

\begin{abstract}
The need for residential property in Jakarta continues to increase, especially for MBR (Low Income Society). The development of TOD (transit-oriented development) area in Jakarta should be able to answer the problem. The existence of MBR dwellings in the form of RUSUNA (simple flats) in transit areas should be a concern because they need more residential and public transportation. Their existence will maximize the use of mass transport and keep the transit area from exclusivity, then the sustainability of the TOD Area is maintained. The problem of RUSUNA TOD development lies in the high price of land and the absence of related regulation, so the developer or manager of TOD is reluctant to develop it. From these problems came the research question, it is true that the majority of transit users are MBR, so that the provision of RUSUNA TOD needs to be maximized. Then, what is the percentage of RUSUNA units required based on transit requirements. The method used is the mix method by spreading the questionnaires to the users of transit, the market of residential users of LebakBulus, and interviews to the experts and stakeholders. The data obtained will be analyzed and adjusted to the applicable regulations.
\end{abstract}

\section{Introduction}

Based on BPS data (Central Bureau of Statistics) 2017 the population of Jakarta every year increases one hundred thousand inhabitants. During the last two years the population of Jakarta increased 269 people every day.[1]Rapid growth leads to high density so there is less land available. The depletion of the number of land makes the value of land in this city higher and not affordable by people, especially low-income people. In the end they tend to stay away from downtown and spend more to do activities in the city.

Along with population growth, demand for residential property in DKI Jakarta is also higher. According to AmranNukman, chairman of REI (Real Estate Indonesia) the need for residential property in Jakarta in 2018 is still quite high, especially for middle lowmarket.[2] This is not comparable with the number of existing housing,Some people who live in the suburbs but still still have activities in the city also cause other problems, that is traffic jams. They judge the existence of mass public transportation that has not been maximized and more efficient using private vehicles.

This can actually be overcome by re-arranging the city's development with more compact. The existing land use system should be able to influence the movement of vehicles so that mobility and urban growth are more efficient. The concept is to close the distance of housing and other activity centers with several mass public transport modes. With the aim of centralizing activities around the transit area and minimizing the use of private vehicles, this concept is then known as the term TOD (Transit-Oriented Development).[3]

Thus the development of the TOD area in Jakarta should also pay attention to the construction of residential property. Residential property in question is a vertical housing considering the limited land in the area. Another thing to note as described by calthrop about the main component of TOD in "The Next American Metropolis" that the development of residential in the TOD region should be diverse and reach all people.[4]

ShastrySrikanth in 2010 explained that the role of diversity in the concept of 3D (density, diversity, and design) - Robert Cevero on understanding TOD not only presents a mixed-use area but also accommodate all the people among others by presenting housing for lowincome communities in the region.[5]A complete and compact area, supported by easy access to public transportation make the value of land in the TOD region is increasing. Without an inclusive housing strategy, the high value of land will cause the area to be dominated by the middle up class property market and lead to the exclusion of the poor or so-called gentrification.[6]In addition, the benefits of the existence of occupancy for low income communities is to prevent the area of TOD into an exclusive and segmented area only for middle up class.

* Corresponding author: berrycbasyir@gmail.com 


\section{Objective of Study}

The presence of low-income housing in the form of RUSUNA (public vertical housing) in the transit area also plays a role in maintaining the sustainability of TOD. The use of mass public transport in Jakarta is still dominated by low-income people. So to maximize the use is by closer their residence with the transit area.Meanwhile, the development of RUSUNA for low income people is certainly not proportional to the high land value in the TOD area.

The purpose of this study is to find the right number of units in developing RUSUNA in TOD Jakarta area with the TOD LebakBulus case study. Due to the main problem of this research is the value of land and high construction cost, then this RUSUNA development must be mature calculation so that the cost incurred in proportion to the benefits gained.

Therefore this research will focus more on determining the number of RUSUNA units as appropriate. The research question asked is whether it is appropriate to provide unit RUSUNA TOD in large quantities?

\section{Literature Review}

\subsection{RUSUNA (affordablevertical housing)}

Indonesian people termed Rusunas a vertical housing intended for the middle to lower class and apartemen (apartments) is intended for middle to upper. Meanwhile the prevailing laws and regulations in Indonesia Rusun is a general term used to describe all types of vertical housings, applies to luxury towers or public flat. so to distinguish the term Rusun as a flat for low income the government issued the term RusunUmum(public vertical housing) which later developed into RUSUNA(simple vertical housing). RUSUNA consist of RUSUNAWA (rent) and RUSUNAMI (owned).

The finance minister in 2015 issued a regulation on the selling price of a modest flat unit which stated that RUSUNA's target market is MBR (lowincome society) and the unit price should not exceed 250 million. In the regulation it is also mentioned that the minimum area of the unit is $21 \mathrm{~m} 2$ and its maximum area is $36 \mathrm{~m} 2$.[6]The term MBR itself refers to the PUPR minister's regulation of earning less than Rp.7,000,000.

In the republic indonesia Law no.20 of 2011 onrumahsusun(theflats), mentioned several things to consider in the development plan of the apartment is:

- building density;

- population size and density;

- detailed spatial plans;

- general infrastructure, utilities and utilities services;

- transportation mode services;

- alternative development concept use of flats;

- information and communication services;

- balanced residential concept; and

- analysis of the potential needs of flats
The law also stipulates that the perpetrators of the construction of commercial flats are required to provide a minimum $20 \%$ of the total commercial floors of the developed commercial flats (RUSUNA) that can be built outside the Regions but in one district / city. [7]

The other regulations related to the obligations of developers in providing housing for the MBR such as balanced housing policy by the Ministry of PUPR (Public Works And Housing) is the concept of comparison 1: 2: 3 , which is 3 for MBR, 2 for middle income communities, and 1 for high income society. The next is the Ministry of BUMN (Ministry of StateOwned) which requires all state-owned companies to develop hobbies near the station to allocate $30 \%$ of the occupancy for the MBR. If the percentage of the procurement obligation is considered minimal, whereas the demand for MBR occupancy is still high.

\subsection{TOD in Jakarta}

The development of the TOD area in Jakarta has been heavily discussed over the last few years, especially since the issuance of Jakarta Governor Regulation no. 44 of 2017 on the development of TOD area. The Governor Regulation includes four matters: Principles of planning, classification and development criteria for TOD; TOD development mechanism; Technical guidance of TOD area utilization; Development and management.

In the regulation described that the technical criteria in developing TOD is a region with a minimum radius of 350 meters with the carrying capacity of mass public transport and environmental carrying capacity. While the general criteria for the development of the TOD area is in the intersection of mass transport (at least two, one of which is rail-based), is a region with high economic value as well as the planned area as the center of activity.[8]

The regulation has not included more detail on the planning of residential areas, thus the fulfillment of dwelling needs in Jakarta which is more appropriate if developed in the TOD area has not become a special attention of Jakarta government.

One of the TOD projects we often hear is a TOD project developed by MRT, this is in accordance with Governor Regulation No.140 of 2017 which appointed PT. MRT Jakarta as the main operator of TOD area management.[9] In accordance with MRT infrastructure development, the development of TOD area in the early phase (north - south corridor) will be developed at several points.

At least of the 13 stations built on the first phase of the MRT project, eight of which will be developed transit-based shelter. William Sabandar as the president director of PT MRT Jakarta at the end of 2017 stated that the dwelling that will be provided also accommodate the occupancy for low income people. One of them at LebakBulus MRT station, in the area will be built aaffordable housing, cheap apartments, office and commercial areas. But the construction of residential property is still in the planning stage of the masterplan, 
currently development is still focused on infrastructure and MRT stations.

Until now the existing TOD regulation has not been included with details related to the procurement of housing in the area, let alone related to housing for lowincome communities. Thusthe fulfillment of actual shelter needs more appropriate if developed in the TOD area has not become a special attention of the government.

\subsection{Affordable Housing In TOD Area}

Responding to the high value of land in the TOD area, some cities in developed countries use the potential value of the land by commercializing some land and investing it to finance the transit and social infrastructure.[11] The construction of affordable housing in the TOD area has been a concern in several countries, various strategies have been prepared for the development and sustainability of the project.

JyothiChava and Peter Newman proposed that necessary deliberations among relevant stakeholders in developing affordable housing on TOD. Deliberation is divided into three levels: inform, involve, and collaborate. They also grouped several tools in guiding the development of affordable housing into several categories:[12]

- Tools related to zoning regulations, local codes, fees, and procedures

- Financing tools

- Joint Development Programs Tools

A paper entitled "Affordable Housing in TransitOriented Developments: Impacts on Driving and Policy Approaches" in 2017 tries to find a common policy point that promotes affordable housing units on TOD development. [13]

The conclusions of the study are:

- Affordable TOD housing will still be affordable if only subsidized by the developer or occupant is sustainable.

- There are at least three benefits of affordable housing development in the TOD area: reducing the living cost of MBR, transit users living in TOD rarely override lease payments, reducing air pollution by reducing personal drivers.

- The policy recommendations on this matter are, increasing the supply of affordable housing units to TOD, increasing subsidies for affordable TOD units, taking decisive action for affordable residential developers out of the subsidized unit market.

Developing RUSUNA in the TOD area of Jakarta may seem difficult to realize given the high price of land in the area. But it is also seen more widely the existence of affordable housing can provide several benefits. The presence of RUSUNA can reduce the cost of living of the MBR, they can cut transport costs are quite burdensome. And provide a more decent life with a healthy environment and complete facilities, which indirectly educate MBR to choose a better lifestyle.

Linking RUSUNA with transit makes them use public transport more often and minimize the use of private vehicles. It has a big impact such as breaking down congestion, reducing the use of fuel, and reducing air pollution in Jakarta.

\section{Methodology}

The method chosen in this study is a mixed method based on Creswell's (2009) theory in the third edition of Research Design. In the book explained that the mix method is a combination of quantitative methods (numerical data) and qualitative (text analysis). The mixed method chosen is the simultaneous mix method. This method combines quantitative and qualitative data to obtain a comprehensive outcome of the research problem.

Based on research questions about determining the exact RUSUNA unit requirements in the TOD area of Jakarta, the approach I use in this study is market analysis. Market analysis is one of the first considerations in developing a property project. Market analysis can be done by studying the needs (demand) and supply (supply) in a region (market area).

According to the book that in determining the market of multifamily housing required are: (1) Identification of area (availability of land, existing market), 2. Market demand factors (occupation, income, population, number of households), and 3. Provision factors (Competitive analysis, measuring development costs, calculating capture rates)

Meanwhile, according to the guideline issued by Mixed-Income Housing TOD Action Guide the initial steps to consider in developing housing with mixed income are: 1. Demographic conditions, 2. Housing market conditions, 3. Availability of land, and 4. Environmental policy.

From both the above theories I tried to summarize and simplify it. Because the area under study is a TOD I am trying to add transit users in analyzing the RUSUNA market on TOD. As for the provision of housing factor I changed the term to a feasibility study. So get 3 stages of research as follows:

1. Market analysis around TOD LebakBulus area
a. Availability of land
b. Environmental policy
c. Demographic conditions
d. Housing market conditions

2. Market analysis of transit users in Jakarta

To know the condition of RUSUNA market in TOD, I will spread the questionnaire to some employees around LebakBulus and public transport users. This method includes quantitative methods and is intended to record what percent of RUSUNA needs are based on the data obtained. From quantitative data I will get RUSUNA TOD LebakBulus unit requirement, indirect data I use but I adjust to regulation condition in Area. It should be noted such as land area, KDB and KLB.

Next I will try to interview and discuss the data obtained with some relevant stakeholders such as PT MRT Jakarta, Totalindo and several other stakeholders. The results of this discussion will make the quantitative data available in qualitative data. 


\section{Result and Discussion}

\subsection{Case Study LebakBulus TOD}

Transit-oriented Development Area which will be used as a case study in this research is LebakBulus MRT station. This Station is part of the first phase of MRT Jakarta project. The station will also function as MRT depot, in which there are workshopsand parking spaces for MRT train.

The LebakBulus MRT station is located on Jl. TB. Simatupang and Jl. LebakBulus Raya. This area is also traversed by the outer ring road and Jakarta - Bogor toll road.Thus the movement of transportation in the area is quite high because it is at a major crossroads, but also as an access to the city of Tanggerang. This station will also be integrated directly with Transjakarta shelter and some other public transportation. With a large area of TOD lebakbulus is planned to cover the office area, housing, and commercial area.TOD LebakBulus area can be categorized as a new TOD area because the area is still empty so that it can be developed maximally.

Regarding the increase / exceedance of KDB and KLB on land in the TOD area is possible with the approval of the governor and the consideration of BKPRD, especially if the land belongs to the Provincial Government of DKI Jakarta. This is stated in Governor Regulation no. 44, by 2017 ,

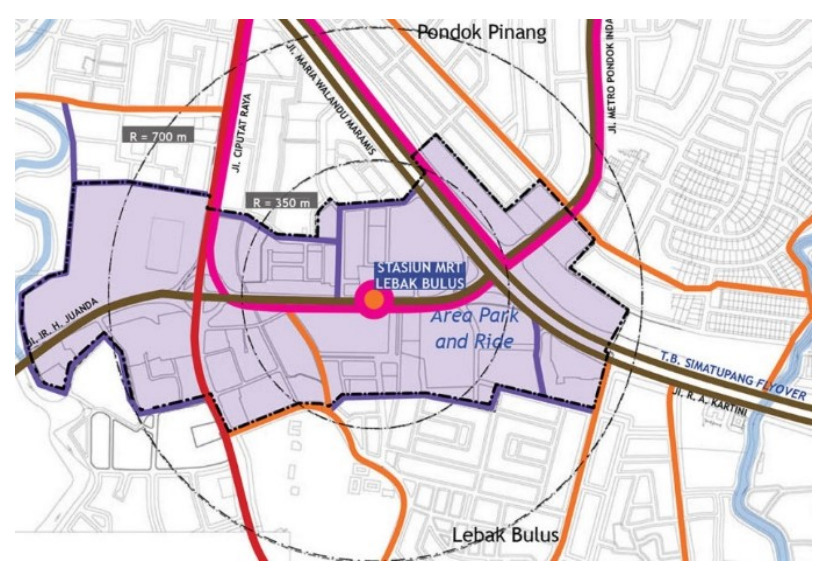

Fig. 5.1 Location of TOD LebakBulus

\subsection{RUSUNA Unit Requirement on TOD LebakBulus}

To find out how much the RUSUNA needs in the TOD area of Jakarta can use the market analysis method as described in the previous methodology chapter. This chapter will attempt to present results and analysis consisting of: Analysis of RUSUNA markets around TOD LebakBulus area (case study); and Market analysis of transit users in Jakarta.

\subsubsection{Land Supply and Policy environment}

I try to choose a strategic planned area around TOD LebakBulus area and get the land behind poins square which turns out to be a land owned by PEMPROV DKI Jakarta. Precisely on Jl. H. Ilyas RT.009 RW.007,
LebakBulus village, Cilandak sub-district, South Jakarta city. This area has direct access to Jalan TB. Simatupang and JalanAdiaksa Raya and is $350 \mathrm{~m}$ away to MRT station.

The planned area is 23,951 sqm. Zoning allotment of the land is a mixed use with initial KDB (Building Coverage Ratio) 30\% and initial KLB (Floor Area Ratio) of 3.00. minimum $\mathrm{KDH}$ (green area) is $45 \%$ and maximum building height by KKOP (Aviation Safety Operation Area)is $110 \mathrm{~m}$. To optimize the land developers can apply for the increase of KDB and KLB value to $40 \%$ and 6.00 to PEMPROV DKI Jakarta.The price of land around the area for now reaches $\mathrm{Rp}$. $25,000,000-30,000,000 / \mathrm{m} 2$.

\subsubsection{Demoraphic conditions}

Kelurahan (urban village) of LebakBulushas an a area of $4,11 \mathrm{Km} 2$ with a population of 39,937 and the number of household is 12.654.Consisting of 20,079 men and 19,858 women with a total family head of 12,654 . The population growth in the village of LebakBulus reached $14.49 \%$.

Regarding data about the income of urban village lebakbulus I have not managed to get, but I will show the income data of the workers around LebakBulus that I get from Questionnaire results and will be discussed in the sub-section of Market Housing Condition. when viewed from the number of luxury housing in the village can be concluded that most of the population in the region is upper middle class.

Therefore, the development of RUSUNA in the TOD area of Jakarta is needed to answer the need for housing for MBR in LebakBulus urban village which during this time may be controlled by middle to upper market. This also prevents the tendency of exclusivity in LebakBulus TOD Area.

\subsubsection{Housing Market Conditions}

Kelurahan Lebak Bulus has a lot of housing, especially landed housing. If you notice the housing market in lebakbulus is dominated by middle and upper middle market, but in this area also found some villages and illegal housing that have difficult access to reach public transport.

This village does not have landed housing for MBR or RUSUNA therefore the existence of RUSUNA TOD is expected to answer the need for MBR market. The existence of RUSUNA certainly not only to accommodate people lebakbulus but also other people who move around lebakbulus like citizens of the countertop and other suburbs area.

Previously I had randomly distributed questionnaires to several companies around LebakBulus and $\mathrm{Jl}$. Tb Simatupang. The questionnaire asked about income, distance of residence and their willingness to live in the TOD area. 


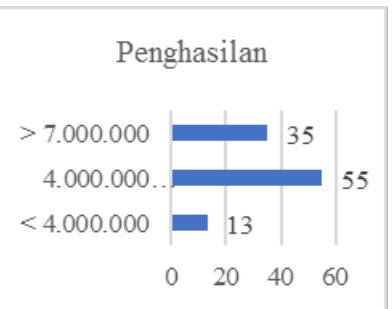

Fig.5.2 Income of respondents

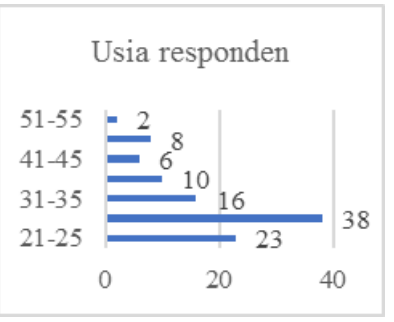

Fig.5.3 Age of respondents
Of the 103 respondents the highest earning range was dominated by 4-7 million in income, followed by $>$ 7 million. This shows that the residential market in the area of lebakbulus dominated by the middle class. From the questionnaire data obtained that as many as 38 respondents are the millennial (21-30 years).

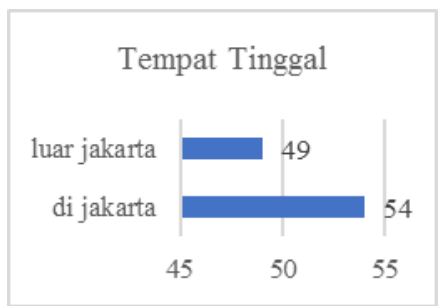

Fig.5.4 residence of respondents

While for residence as many as $54 \%$ live in the city of Jakarta as much as $49 \%$ in suburbs such as counters, some of them live rent a house or room around the office, some still live with parents and some others choose to live in the suburbs.

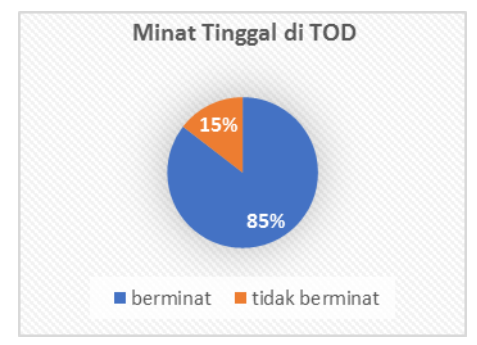

Fig.5.5 interest to settle in TOD

$85 \%$ of respondents are interested in living in TOD area. According to them would be much more efficient if lived in vertical dwellings and near transit. Small unit sizes do not matter as long as the price offered is cheap, this is because most of them are low-income and unmarried.

Due to this area of development being a transit area, I also tried to spread the questionnaires to 118 public transport users such as busway and KRL (because MRT is not yet operational I use KRL passengers as respondents).

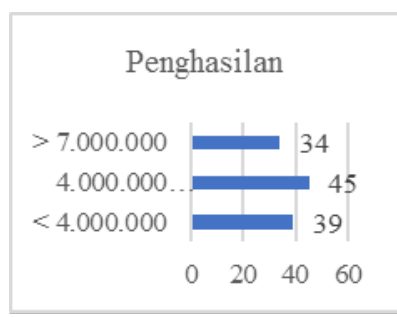

Fig.5.6 income of respondents

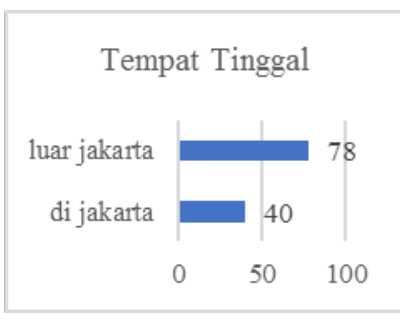

Fig.5.7 age of respondents
The highest income range is dominated by under 4-7 million which is followed by under 4 million. This proves that public transportation users are still dominated by the MBR.However, the existing MBR divided into two that is range $4-7$ million and 4 million down. MBRs earning less than 4 million are feared that they will not be able to pay the installment of RUSUNA which can reach 2.3 million per month.

$78 \%$ of respondents live in suburbs. Prove that most transit users are people who can not afford to buy housing in the middle of the city.

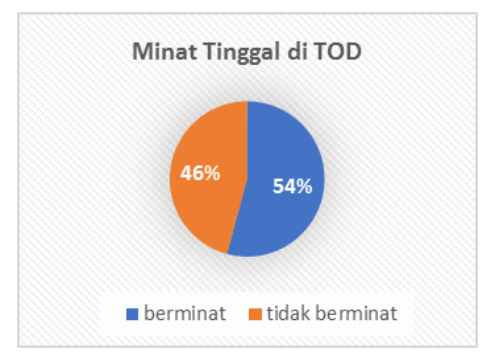

Fig.5.8 interest to settle in TOD

The interest of live transit users in the TOD area was not so much. A total of 64 people are interested and 54 others are not interested. Based on interview results most of the MBR chose to stay in landed rather than vertical dwelling.

To see the market of RUSUNA needs as a wholethenwe must combine the data of workersaroundlebakbulus and transit users. thencalculate the number of respondentswho are interested in living in TOD and earn $4-7$ million / month. So obtained the followingresults :

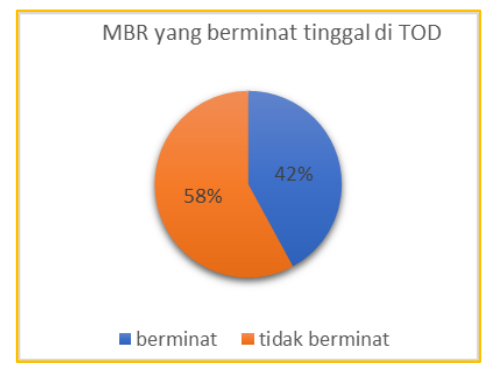

Fig.5.9 interest to settle in TOD

The resultis as much as $42 \%$ of the total respondents are interested in staying and fallinto the category of MBR whocanpay the mortgage. While the remaining $58 \%$ wereinterestedrespondents but did not include the MBR category and alsowere not interested and did not belong to the category.The mostpromisingmarketis the workersaroundLebakBulus. Meanwhile, to find out how the Supply of RUSUN requiredfeasibilitycalculation.

Based on marketanalysis, the development of RUSUNA in the TOD area isfeasible to develop, and the market of MBR as demandfrom RUSUNA has a considerableamount.

\subsection{Expert Opinions and Stakeholder Related}


According to LuhputudyahChandrawati as Design and Build Coordinator PT TotalindoEkaPersada market from TOD LebakBulus is middle up like TOD DukuhAtas. To get return from the development of property depends on the composition of the planned mixed use so that the commercial area can subsidize the residential area but it is different with LebakBulus area this area is a luxury residential area and will be more profitable if intended for middle up. These considerations are also based on suggestions from marketing consultants or business development in cooperation with Totalindo.

According to Anna KuntiPratiwias director of marketing PERUMNAS, the development of RUSUNA in TOD Area with maximized number of units may be done of course with the calculation of mature business and support from the government especially regulation, licensing and ease of financing. Perumnas has been accustomed to providing housing for middle and middle low so that it will be better prepared in terms of business calculations. Perumnas itself has a mission from the government to overcome the backlog of housing, but still take into account the profits that a private company deserves.

According to EppiPribudhi as a private developer and one of the officials REI (Real Estate Indonesia). RUSUNA is likely to be developed in the TOD area, considering the lower middle housing market more so that the return on investment is faster. To get around the development costs can be by using finishing materials are cheaper, the unit is usually unfurnished, and the use of elevators are divided into several floors so as not to wasteful. The composition of RUNAMI (owned) can be combined with RUSUNAWA (rent) so that not all units sold and developers can benefit RUSUNAWA as an asset that can be converted into condotel.

\section{Conclusion}

Based on market analysis, the development of RUSUNA in the TOD area is feasible to develop, and the market of MBR as demand from RUSUNA has a considerable amount (42\%). However, not all MBR people can have it because thosee arning less than 4 million will find it difficult to pay for monthly shelter over $30 \%$ of their income. Therefore, other types of shelter that can meet the needs of shelter for MBR who earn less than 4 million, which generally also use public transportation.

The supply of RUSUNA TOD in large quantities may be done with the support of the government such as licensing and financing regulations and will be more easily implemented if the land developed is owned by the government. TOD managers are required to urge developers to the importance of providing shelter for MBR. In additionthe Government also needs to prepare regulations related to the procurement of MBR shelter in the TOD Area.

\section{References}

[1] "Badan Pusat Statistik. Pertumbuhan Penduduk
Jakarta," (2017)

[2] E. Rusyanto, "beritasatu.com," berita satu, 5 december 2017. [Online]. Available: http://id.beritasatu.com/property/rei-kebutuhanhunian-di-jakarta-masih-cukup-tinggi/168926. [Accessed 20 march 2018].

[3] R. Cervero and K. Kockelman, "Travel demand and the 3Ds: Density. diversity. and design," Transportation Research Part D: Transport and Environment, pp. 199 -219, (1997)

[4] P. Carlthorp, The Next American Metropolis : Ecology, Community, and The American Dreams, New York: Princeton Architectural Press, (1997)

[5] S. Shastry, "Spatial Assessment of Transit Oriented Development," University of Twente, Ahmedabad, (2010)

[6] "Peraturan Mentri Keuangan Republik Indonesia Nomor 269," In Batasan Harga Jual Unit Hunian Rumah Susun Sederhana Milik Dan Penghasilan Bagi Orang Pribadi Yang Memperoleh Unit Hunian Rumah Susun Sederhana Milik, 2015.

[7] "Undang - Undang Republik Indonesia No 20 Tahun 2011 Tentang Rumah Susun".

[8] "Peraturan Gubernur Provinsi Daerah Khusus Ibukota Jakarta Nomor 44 Tahun 2017 Tentang Pengembangan Kawasan TOD".

[9] "Peraturan Gubernur Provinsi Daerah Khuss Ibukota Jakarta Nomor 140 Tahun 2017 Tentang: Penugasan PT MRT Jakarta Sebagai Operatc Utama Pengelola Kawasan TOD Koridor (Utara Selatan) Fase I Mass Rapid Transit Jakarta.

[10] inapex.co.id, "jakartamrt.co.id," MRT Jakarta, 3 november 2017. [Online]. Available: https://www.jakartamrt.co.id/2017/11/03/8stasiun-mrt-jakarta-bakal-dikembangkan-huniantod/. [Accessed 26 january 2018].

[11] P. Newman and J. Kenworthy, The End of Automobile Dependence: How Cities are Moving Beyond Car-Based Planning (Washington DC, Island Press, 2015)

[12] J. Chava and P. Newman, "Stakeholder Deliberation on Developing Affordable Housing Strategies: Towards Inclusive and Sustainable Transit-Oriented Developments," 13 October 2016.

[13] M. G. Boarnet, R. Bostic, D. Williams and R. S. Bartolomei, "Affordable Housing in TransitOriented Development: Impacts on Driving and Policy Approaches," A National Center for Sustainable Transportation Research Report, 2017.

[14] M. Austin, A. Brooks, W. J. Dong Jr. and R. Hickey, "MIXED-INCOME HOUSING TOD ACTION GUIDE," The Center for TransitOriented Development for the Great Communities Collaborative, (2009)

[15] "selatan.jakarta.go.id," Kota Administrasi Jakarta Selatan, [Online]. Available: 
http://selatan.jakarta.go.id/kecamatan_cilandak/?pa $\mathrm{ge}=$ Kependudukan. [Accessed 4 april 2018].

[16] Badan Pusat Statistik. Jumlah Penumpang dan Pendapatan Trans Jakarta menurut Koridor atau Rute, (2017)

[17] "jakarta.go.id," PEMPROV DKI Jakarta, 2014. [Online].Available:

http://dcktrp.jakarta.go.id/beranda/peraturan/Jakart a\%20Selatan01.pdf. [Accessed 3 april 2018].

[18] J. W. Creswell, Research Design: Qualitative, Quantitative, and Mixed Methods Approaches. 3rd ed (Lincoln: SAGE Publications. Inc, 2009) 